No 4078

Studia nad Autorytaryzmem i Totalitaryzmem 43, nr 4 Wrocław 2021

https://doi.org/10.19195/2300-7249.43.4.35

\author{
ŁUKASZ PRUS \\ ORCID: 0000-0002-0990-3666 \\ Uniwersytet Wrocławski \\ lukasz.prus@uwr.edu.pl
}

\title{
Służba na rzecz totalitarnego państwa jako przesłanka obniżenia zaopatrzenia emerytalnego funkcjonariuszy zatrudnionych w organach bezpieczeństwa w latach 1944-1990
}

Słowa kluczowe: służba na rzecz totalitarnego państwa, prawo do sądu, emerytura.

\author{
SERVICE IN A TOTALITARIAN STATE AS A BASIS FOR REDUCING THE PENSION \\ OF OFFICERS EMPLOYED IN THE SECURITY SERVICE IN THE YEARS 1944-1990
}

\begin{abstract}
The paper describes term of service in a totalitarian state as a basis for reducing the pension of officers employed in the security service in the years 1944-1990. The legislators decided to hold liable the officers of the communist political police by reducing their pensions again, 26 years after the transformation. In this aspect, the crucial issue is the concept of service in a totalitarian state. The thesis of the paper is that the qualification of service in a totalitarian state cannot be determined only by formal conditions, that is, the time and place of service, but should also take into account substantive criteria, especially violation of the fundamental rights of individuals by former officers.
\end{abstract}

Keywords: service in a totalitarian state, right to court, pension. 


\section{Uwagi wstępne}

W dniu 16 grudnia 2016 roku została wprowadzona kolejna modyfikacja systemu obliczania świadczeń z ubezpieczeń społecznych dla funkcjonariuszy służb mundurowych, którzy wstąpili w ich szeregi przed 1990 rokiem ${ }^{1}$. Motywem drugiej ustawy dezubekizacyjnej nie było na przykład odkrycie nieznanych dotąd okoliczności na temat represyjnej działalności funkcjonariuszy konkretnych służb. Ratio legis tej regulacji polega na wprowadzeniu ustawowego mechanizmu, który w pełniejszy sposób zniesie przywileje emerytalne pracowników aparatu bezpieczeństw PRL ${ }^{2}$. Projektodawcy przyznali, że poprzednia regulacja, tak zwana pierwsza ustawa dezubekizacyjna z 2009 roku $^{3}$, okazała się nieskuteczna

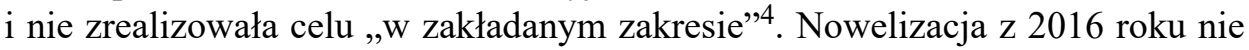
ma zatem swojego autonomicznego celu, lecz odwołuje się do ratio legis pierwszej ustawy dezubekizacyjnej. W preambule tej ostatniej ustawodawca stwierdził, że system komunistyczny opierał się na policji politycznej, która naruszała podstawowe prawa człowieka oraz dopuszczała się zbrodni wobec osób broniących niepodległości i demokracji, przy jednoczesnym wyjęciu sprawców spod odpowiedzialności prawnej ${ }^{5}$. Dlatego projektodawcy obu ustaw uznali, że

niedopuszczalne jest dalsze trwanie systemu prawnego, który przewiduje dla tych osób (tj. byłych funkcjonariuszy organów bezpieczeństwa państwa oraz WRON) wysokie przywileje emerytalne, szczególnie w kontekście trudnej obecnie sytuacji materialnej wielu ludzi walczących w tych latach o wolność, niepodległość i prawa człowieka ${ }^{6}$.

1 Jedynie na marginesie warto odnotować, że Ustawa z dnia 16 grudnia 2016 roku o zmianie ustawy o zaopatrzeniu emerytalnym funkcjonariuszy Policji, Agencji Bezpieczeństwa Wewnętrznego, Agencji Wywiadu, Służby Kontrwywiadu Wojskowego, Służby Wywiadu Wojskowego, Centralnego Biura Antykorupcyjnego, Straży Granicznej, Biura Ochrony Rządu, Państwowej Straży Pożarnej i Służby Więziennej oraz ich rodzin (Dz.U. z 2016 r. poz. 2270) została uchwalona w trakcie nietypowego głosowania w Sali Kolumnowej Sejmu, zob. A. Rakowska-Trela, Obniżenie emerytur funkcjonariuszy służb mundurowych nabytych poczawszy od 1990 r. a standardy konstytucyjne, „Gdańskie Studia Prawnicze” 40, 2018, s. 275-276.

2 Źródło: https://bit.ly/3pAUF42 (dostęp: 6.10.2021).

3 Ustawa z dnia 23 stycznia 2009 roku o zmianie ustawy o zaopatrzeniu emerytalnym żołnierzy zawodowych oraz ich rodzin oraz ustawy o zaopatrzeniu emerytalnym funkcjonariuszy Policji, Agencji Bezpieczeństwa Wewnętrznego, Agencji Wywiadu, Służby Kontrwywiadu Wojskowego, Służby Wywiadu Wojskowego, Centralnego Biura Antykorupcyjnego, Straży Granicznej, Biura Ochrony Rządu, Państwowej Straży Pożarnej i Służby Więziennej oraz ich rodzin (Dz.U. z 2009 r. $\mathrm{Nr} 24$, poz. 145).

${ }^{4}$ Nie wyjaśniono jednak, jaki był ten zakładany cel.

5 Ustawa z dnia 23 stycznia 2009 roku o zmianie ustawy o zaopatrzeniu emerytalnym żołnierzy zawodowych oraz ich rodzin oraz ustawy o zaopatrzeniu emerytalnym funkcjonariuszy Policji, Agencji Bezpieczeństwa Wewnętrznego, Agencji Wywiadu, Służby Kontrwywiadu Wojskowego, Centralnego Biura Antykorupcyjnego, Straży Granicznej, Biura Ochrony Rządu, Państwowej Straży Pożarnej i Służby Więziennej oraz ich rodzin (Dz.U. z 2009 r. Nr 24, poz. 145).

${ }^{6}$ Źródło: https://bit.ly/3pAUF42 (dostęp: 6.10.2021). 
Pierwsza ustawa dezubekizacyjna z 2009 roku obniżyła podstawy wymiaru świadczenia emerytalnego z $2,6 \%$ do $0,7 \%$ za każdy rok pracy w aparacie bezpieczeństwa PRL ${ }^{7}$. Druga — z 2016 roku — zredukowała ten współczynnik do 0,0\% za każdy rok pracy służby na rzecz totalitarnego państwa w latach $1944-1990^{8}$. Praca tych osób, które były zatrudnione w służbach bezpieczeństwa także po 1990 ro$\mathrm{ku}$, jest przeliczana po $2,6 \%$ za każdy rok pracy ${ }^{9}$, przy czym ich świadczenie nie może być wyższe niż miesięczna kwota przeciętnej emerytury wypłaconej przez Zakład Ubezpieczeń Społecznych z Funduszu Ubezpieczeń Społecznych (art. 15c ust. 1 i 3 Ustawy z dnia 18 lutego 1994 roku o zaopatrzeniu emerytalnym funkcjonariuszy Policji, Agencji Bezpieczeństwa Wewnętrznego, Agencji Wywiadu, Służby Kontrwywiadu Wojskowego, Służby Wywiadu Wojskowego, Centralnego Biura Antykorupcyjnego, Straży Granicznej, Straży Marszałkowskiej, Służby Ochrony Państwa, Państwowej Straży Pożarnej, Służby Celno-Skarbowej i Służby Więziennej oraz ich rodzin, dalej jako ,ustawa zaopatrzeniowa ${ }^{10}$ ). Ponadto zgodnie $\mathrm{z}$ art. 22a ust. 1 ustawy zaopatrzeniowej funkcjonariuszom służb bezpieczeństwa PRL zmniejszono rentę inwalidzką o 10\% podstawy wymiaru za każdy rok służby na rzecz totalitarnego państwa. W końcu druga ustawa dezubekizacyjna na mocy art. 24a zredukowała wysokość renty rodzinnej po funkcjonariuszach aparatu bezpieczeństwa PRL, którzy pozostawali w służbie przed dniem

7 Przed wejściem w życie pierwszej ustawy dezubekizacyjnej ten przelicznik wynosił 40\% podstawy wymiaru świadczenia emerytalnego po 15 latach pracy, za każdy rok, zob. M. Dąbrowski, Odpowiedzialność funkcjonariuszy Policji i innych współczesnych formacji za petnienie stuzby $w$ organach bezpieczeństwa PRL - aspekty konstytucyjne, „Przegląd Prawa Konstytucyjnego” 2018, nr 2, s. 124.

8 Dla przykładu można wskazać, że w sprawie, w której Sąd Najwyższy wydał uchwałę siedmiu sędziów z dnia 16 września 2020 roku, sygn. akt III UZP 1/20, na skutek pierwszej ustawy dezubekizacyjnej powodowi w 2009 roku obniżono emeryturę do kwoty 1184,46 zł, natomiast w 2017 roku, po kolejnej nowelizacji zredukowano ją do kwoty 91,27 zł. Jednakże podwyższono ją do kwoty minimalnego świadczenia. Co ciekawe, ustawa lepiej traktuje skazanych przez sąd funkcjonariuszy. Zgodnie z art. 10 ust. 1 ustawy zaopatrzeniowej prawo do zaopatrzenia emerytalnego na podstawie tej ustawy nie przysługuje funkcjonariuszowi, który został skazany prawomocnym wyrokiem sądu za przestępstwo umyślne lub przestępstwo skarbowe umyślne, ścigane z oskarżenia publicznego, popełnione w związku z wykonywaniem czynności służbowych i w celu osiągnięcia korzyści majątkowej lub osobistej, albo za przestępstwo określone w art. 258 kk lub wobec którego orzeczono prawomocnie środek karny pozbawienia praw publicznych za przestępstwo lub przestępstwo skarbowe, które zostało popełnione przed zwolnieniem ze służby. W takiej sytuacji funkcjonariusz może nabyć prawo do świadczeń z powszechnych ubezpieczeń społecznych, jeżeli spełnia warunki określone w ustawie o emeryturach i rentach z Funduszu Ubezpieczeń Społecznych (art. 10 ust. 4 ustawy zaopatrzeniowej). W konsekwencji za każdy rok pracy przyjmuje się wskaźnik 1,3\% bądź przelicza się staż pracy na kapitał początkowy i składkowy, zob. A. Rakowska-Trela, op. cit., s. $278-279$.

9 Emerytura dla pozostałych funkcjonariuszy, którzy zostali przyjęci do służby po raz pierwszy przed i po dniu 1 stycznia 1999 roku, wynosi $40 \%$ podstawy jej wymiaru za 15 lat służby i wzrasta na zasadach określonych w art. 15 lub art. 15a ustawy zaopatrzeniowej.

10 Tekst jedn. Dz.U. z 2020 r. poz. 723. 
2 stycznia 1999 roku, do wysokości świadczenia, które przysługiwało lub przysługiwałoby zmarłemu $\mathrm{z}$ uwzględnieniem przepisów art. 15c lub art. 22a ustawy zaopatrzeniowej. Konsekwencje prawne drugiej ustawy dezubekizacyjnej co do zasady dotyczą osób, które przepracowały w służbach mundurowych choćby jeden dzień przed 31 lipca 1990 roku $^{11}$.

Treść ustawy z 2016 roku prowadzi do wniosku, że wszystkie te skutki zależą od tego, czy funkcjonariusz spełnia kryteria $\mathrm{z}$ art. 13b ust. 1 ustawy zaopatrzeniowej. Ustawodawca $\mathrm{w}$ tym przepisie, wyznaczając zakres podmiotowy regulacji, zrezygnował z pojęcia, którym posługiwał się w pierwszej ustawie dezubekizacyjnej, to jest - „służby w organach bezpieczeństwa państwa w latach 1944-1990" na rzecz terminu ,służby na rzecz totalitarnego państwa”, który jest rzekomo bardziej adekwatny. Projektodawcy podkreślili, że poprzednie pojęcie okazało się nieprecyzyjne i dlatego sądy nie uznawały za organy bezpieczeństwa poszczególnych jednostek aparatu PRL, co do których Instytut Pamięci Narodowej nie miał wątpliwości, że nimi były ${ }^{12}$. Notabene w tej ostatniej intencji ustawodawcy w istocie wyrażona jest teza, że normatywna ocena historii poparta opinią IPN powinna być wyłączona spod kontroli sądowej, co będzie zasadniczym przedmiotem dalszej analizy.

Zgodnie $\mathrm{z}$ art. 13b ust. 1 ustawy zaopatrzeniowej za służbę na rzecz totalitarnego państwa uznaje się pracę od dnia 22 lipca 1944 do 31 lipca 1990 roku $\mathrm{w}$ enumeratywnie wymienionych tam cywilnych i wojskowych instytucjach oraz formacjach. W tym miejscu powstaje pytanie, czy tak przyjęte środki są zgodne $\mathrm{z}$ celem ustawy. To zaś determinuje zasadnicze wątpliwości, czy o służbie na rzecz państwa totalitarnego zgodnie z wykładnią językową decydują kryteria formalne, to jest - czas i miejsce służby, czy też mając na względzie wykładnię celowościową i systemową, należy dodatkowo wykazać indywidualną działalność represyjną, która polegała na popełnieniu zbrodni wobec osób dążących do przywrócenia niepodległości i demokracji. Kolejnym związanym z tym zagadaniem prawnym jest pytanie, jakie są reguły dowodzenia służby na rzecz państwa totalitarnego. Innymi słowy, czy organ emerytalny i sąd związane są informacją IPN o przebiegu służby na rzecz totalitarnego państwa. Przedmiotem analizy będzie też pytanie, czy taka ustawowa konstrukcja zapewnia prawo do skutecznego środka prawnego. Aby udzielić odpowiedzi na tak zadane pytania, w pierwszej kolejności należy ustalić treść pojęcia służby na rzecz państwa totalitarnego.

11 Trzeba jednak odnotować, że zgodnie z art. 13c pkt 1 ustawy zaopatrzeniowej skutków ustawy nie stosuje się do służby, która rozpoczęła się po raz pierwszy nie wcześniej niż w dniu 12 września 1989 roku. Natomiast zgodnie z art. 8a ustawy zaopatrzeniowej minister właściwy do spraw wewnętrznych może wyłączyć stosowanie tych skutków w określonych przypadkach. Zob. M. Dąbrowski, Glosa do uchwaty składu siedmiu sędziów Sądu Najwyższego z dnia 16 września 2020 r., sygn. akt III UZP 1/2020, „Przegląd Prawa Konstytucyjnego” 2021, nr 3, s. 366-367.

12 Źródło: https://bit.ly/3pAUF42 (dostęp: 6.10.2021). 


\section{Służba na rzecz totalitarnego państwa}

Pojęcie służby na rzecz totalitarnego państwa składa się z trzech kluczowych elementów. Pierwszym jest termin „służba na rzecz”, drugi to „totalitarne państwo" z jasno zakreślonymi ramami czasowymi tego państwa oraz trzeci element, czyli zamknięty katalog cywilnych i wojskowych instytucji oraz formacji.

Jeżeli chodzi o ten ostatni element, należy stwierdzić, że, z jednej strony, katalog zamkniętych formacji działających na rzecz ustroju totalitarnego jest dość szeroki i obejmuje w zasadzie wszystkich pracowników tych jednostek bez względu na to, czy wykonywali oni obowiązki operacyjne, represyjne, politycznej propagandy, czy też urzędnicze i pomocnicze lub związane $\mathrm{z}$ ochroną bezpieczeństwa i porządku publicznego bądź granic. Z drugiej zaś — katalog jest jednak wąski względem ratio legis ustawy, ponieważ nie obejmuje na przykład członków władzy odpowiedzialnych za podejmowanie decyzji lub rozkazów, które były powodem naruszenia praw człowieka, a także prokuratorów lub sędziów, którzy brali udział w sprawach politycznych ${ }^{13}$.

Jednakże w judykaturze i doktrynie najwięcej wątpliwości budzi drugi element definicji. Nie ma bowiem konsensusu naukowego co do definicji totalitaryzmu oraz kwalifikacji poszczególnych ustrojów. Dyskurs nad znaczeniem tego pojęcia trwa od XX wieku. Pojęcia totalitaryzmu używa się w odniesieniu do rządów lub ruchów społeczno-politycznych, które mają na celu kompleksowe i totalne kontrolowanie wszystkiego w społeczeństwie. Państwa totalitarne z reguły odrzucają pluralizm myślenia i narzucają społeczeństwu własną ideologię ${ }^{14}$. Hannah Arendt wskazała, że walka o totalną dominację nad społeczeństwem i eliminacja konkurencji są nieodłącznymi cechami totalitarnych reżimów. Władza totalitarna wykorzystuje przy tym policję polityczną jako wykonawców i strażników utrzymania władzy ${ }^{15}$. W ujęciu $\mathrm{H}$. Arendt istotę totalitaryzmu stanowi nihilizm prawniczy i uprzedmiotowienie wroga, czego celem jest likwidacja ochrony człowieka przed samowolą władzy ${ }^{16}$.

13 Zob. zdanie odrębne sędzi TK Ewy Łętowskiej do wyroku Trybunału Konstytucyjnego z dnia 24 lutego 2010 roku, sygn. akt K 6/09, p. 2; zdanie odrębne sędziego TK Leona Kieresa do wyroku Trybunału Konstytucyjnego z dnia 16 czerwca 2021 roku, sygn. akt P 10/20.

${ }^{14}$ Notabene termin ten pochodzi od włoskiego totalitario, które znaczy 'całkowity, absolutny' i od początku był kojarzony z rządami faszystowskimi Mussoliniego (E. Kamenka, Totalitaryzm, [w:] Przewodnik po współczesnej filozofii politycznej, red. R.E. Goddin, F. Pettit, Warszawa 1998, s. 800-801).

15 H. Arendt, The Origins of Totalitarianism, [w:] On Violence, red. B.B. Lawrence, A. Karim, Durham 2007, s. 419.

16 T. Scheffler, Przestępstwo publicznego propagowania faszystowskiego lub innego totalitarnego ustroju państwa (art. 256 k.k.). Analiza doktrynologiczna wybranych wypowiedzi piśmiennictwa i judykatury. Część szczególna I, „Studia nad Autorytaryzmem i Totalitaryzmem” 40, 2018, nr 4, s. 149. 
Z kolei Carl Joachim Friedrich i Zbigniew Brzeziński do zasadniczych cech totalitaryzmu zaliczyli:

1. oficjalną (czy nawet urzędową) ideologię obejmującą wszystkie istotne aspekty ludzkiej egzystencji, która musi być przestrzegana przez wszystkich;

2. jedną masową partię, która zazwyczaj kierowana jest przez jedną osobę (dyktatora), a która kontroluje administrację państwową;

3. system terrorystycznej kontroli policyjnej;

4. technologicznie uwarunkowany monopol kontroli środków komunikacji masowej;

5. monopol kontroli środków przymusu;

6. centralną kontrolę i kierowanie całą gospodarką ${ }^{17}$.

To podejście przez wiele lat przeważało $\mathrm{w}$ badaniach nad ustrojami państw. Jednakże z czasem coraz częściej dostrzegano, że część tych cech nie jest jednoznaczna, a nawet można je przypisać ustrojom nietotalitarnym. Trudno stworzyć katalog cech modelowego państwa totalitarnego. Według L.B. Shapiro państwa o ustrojach totalitarnych mogą różnić się pod względem zakresu, realizacji celów czy też po prostu ich totalności. Nie jest to niezmienna forma sprawowania władzy. Co więcej, może też przekształcać się w inne formy, jak na przykład podczas przewrotu w 1968 roku w Czechosłowacji. W końcu może w nich występować pewien ograniczony pluralizm, jak na przykład niezależność Kościoła w PRL. Stanowi to potwierdzenie, że pojęcie totalitaryzmu jest trudne do zdefiniowania i podatne na nadużycia demagogów ${ }^{18}$. W nauce nie ma sporu, że do ustrojów totalitarnych można zaliczyć faszyzm, nazizm i stalinizm. Jednakże nie ma jasnej oceny na przykład na temat rządów generała Francisco Franco w Hiszpanii lub Antonio Salazara w Portugali, które raczej zaliczane są do ustrojów autorytarnych ${ }^{19}$. W tych okolicznościach, przy braku konsensusu naukowego, ustawodawca nie powinien przyjmować definicji legalnej pojęcia państwa totalitarnego na zasadzie „wszystko albo nic”, tym bardziej że taka ustawowa ocena historii może być podstawą do kształtowania praw i obowiązków jednostek ${ }^{20}$.

17 Z. Brzeziński, C.J. Friedrich, Totalitarian Dictatorship and Autocracy, New York-Washington-London 1956, s. 9-10.

18 L.B. Shapiro, Totalitarinism, London 1972, s. 124-125.

${ }^{19}$ H. Izdebski, Totalitaryzm i terminy pokrewne w naukach społecznych oraz w polskim języku prawnym i prawniczym, „Studia nad Autorytaryzmem i Totalitaryzmem” 38, 2016, nr 4, s. 32-35.

${ }^{20} \mathrm{Ibidem}$, s. 34. Wprawdzie do tej pory ustawodawca często posługiwał się pojęciem totalitaryzmu, jednak nie definiował jego treści. Przepis art. 13 Konstytucji RP stanowi, że zakazane jest istnienie partii politycznych i innych organizacji odwołujących się w swoich programach do totalitarnych metod i praktyk działania nazizmu, faszyzmu i komunizmu. Zgodnie zaś z art. 256 $\S 1 \mathrm{kk}$ „kto publicznie propaguje faszystowski lub inny totalitarny ustrój państwa [...], podlega grzywnie, karze ograniczenia wolności albo pozbawienia wolności do lat 2". W preambule ustawy z dnia 7 maja 2009 roku o zadośćuczynieniu rodzinom ofiar zbiorowych wystąpień wolnościowych w latach 1956-1989 wyjaśniono, że akt ten został przyjęty w trosce o zachowanie i utrwalenie w pamięci obywateli Rzeczypospolitej Polskiej wystąpień wolnościowych w latach 1956-1989, które doprowadziły do odzyskania w 1989 roku suwerennego i demokratycznego bytu przez państwo 
W doktrynie i orzecznictwie wątpliwości budzą także ustawowo określone ramy czasowe trwania totalitarnego państwa i służby na jego rzecz. Przepis art. 13 b ust. 1 ustawy zaopatrzeniowej za służbę na rzecz totalitarnego państwa uznaje służbę od dnia 22 lipca 1944 do 31 lipca 1990 roku. Innymi słowy, prawodawca przyjmuje, że totalitarne państwo skończyło się dopiero 31 lipca 1990 roku, czyli z dniem ustawowego rozwiązania Służby Bezpieczeństwa i powołania Urzędu Ochrony Państwa ${ }^{21}$. Jednakże historycy powszechnie przyjmują, że stalinizm jako forma totalitaryzmu skończył się w 1956 roku, co oczywiście nie oznacza, iż po tej dacie ustrój PRL można opisać jako demokratyczny ${ }^{22}$. Okres 1956-1989 jest często określany posttotalitarnym autorytaryzmem lub czasem detotalitaryzacji jako opis reżimu niedemokratycznego w fazie rozkładania się totalitaryzmu, ale jeszcze nie rządów demokracji i pluralizmu oraz ochrony praw jednostki ${ }^{23}$. Niezależnie od powyższego ustawowe ramy czasowe służby na rzecz totalitarnego państwa wydają się zbyt szerokie, skoro pierwszy rząd demokratyczny powstał w dniu 12 września 1989 roku, a zasada państwa prawnego w wersji wolnościowej została wprowadzona do porządku prawnego Ustawą z dnia 29 grudnia 1989 roku o zmianie Konstytucji Polskiej Rzeczypospolitej Ludowej ${ }^{24}$.

Jednakże kluczowy w procesie wykładni kryterium służby na rzecz totalitarnego państwa jest właśnie termin „służby na rzecz”. Po pierwsze, ustawodawca polskie oraz mając na względzie między innymi czyny obywateli podejmowane w trakcie zbiorowych wystąpień wolnościowych w latach 1956-1989 w obronie wolności, godności człowieka oraz praw obywatela przed komunistycznym ustrojem totalitarnym. Natomiast preambuła Ustawy z dnia 18 października 2006 roku o ujawnianiu informacji o dokumentach organów bezpieczeństwa państwa z lat 1944-1990 oraz treści tych dokumentów głosi, że praca albo służba w organach bezpieczeństwa państwa komunistycznego, lub pomoc udzielana tym organom, polegające na zwalczaniu opozycji demokratycznej, związków zawodowych, stowarzyszeń, kościołów i związków wyznaniowych, łamaniu prawa do wolności słowa i zgromadzeń, gwałceniu prawa do życia, wolności, własności i bezpieczeństwa obywateli, była trwale związana $\mathrm{z}$ łamaniem praw człowieka i obywatela na rzecz komunistycznego ustroju totalitarnego. Przepis art. 1 pkt 5 Ustawy z dnia 18 grudnia 1998 roku o Instytucie Pamięci Narodowej — Komisji Ścigania Zbrodni przeciwko Narodowi Polskiemu stanowi zaś, że przedmiotem regulacji tej ustawy jest poszukiwanie miejsc spoczynku osób poległych w walkach o niepodległość i zjednoczenie państwa polskiego, a zwłaszcza tych, które straciły życie wskutek walki z narzuconym systemem totalitarnym, represji totalitarnych lub czystek etnicznych w okresie od dnia 8 listopada 1917 do 31 lipca 1990 roku.

21 Notabene ustawodawca w tym zakresie nie jest konsekwentny, gdyż pomimo że deklaruje koniec służby na rzecz totalitarnego państwa w dniu 31 lipca 1990 roku, to jednocześnie uznaje, że kto rozpoczął służbę w aparacie bezpieczeństwa po raz pierwszy nie wcześniej niż w dniu 12 września 1989 roku (data utworzenia rządu T. Mazowieckiego), to nie służył totalitarnemu państwu, zob. art. 13c pkt 2 ustawy zaopatrzeniowej i art. 8a ust. 1 pkt 2 ustawy zaopatrzeniowej .

22 W 1956 roku nastąpiło wiele zdarzeń świadczących o detotalitaryzacji, w tym śmierć B. Bieruta, strajki między innymi w Poznaniu, zwolnienie kardynała Stefana Wyszyńskiego, uwolnienie Władysława Gomułki i amnestia dla żołnierzy AK. W latach osiemdziesiątych pojawiły się takie instytucje, jak rzecznik praw obywatelskich czy sądownictwo administracyjne, Trybunał Konstytucyjny, zob. M. Dąbrowski op. cit., s. 127-128.

23 Ibidem; H. Izdebski, op. cit., s. 33.

24 Dz.U. z 1989 r. Nr 75, poz. 444. 
nie posłużył się zwrotem „służby w”, lecz „służbą na rzecz”. Po drugie, służba na czyjąś rzecz ma charakter indywidualny i kierunkowy. Indywidualny, bo cechuje się osobistym zaangażowaniem w działalność ukierunkowaną na realizację zadań i funkcji tego ustroju ${ }^{25}$. Zwrot „służby na rzecz” ma charakter kierunkowy, bo wymusza zachowanie korzystne z punktu widzenia podmiotu, na rzecz którego służba była wykonywana, czyli „na korzyść” totalitarnego państwa ${ }^{26}$. Nie każde więc nawiązanie stosunku prawnego $\mathrm{w}$ ramach służby skutkowało zindywidualizowanym zaangażowaniem ukierunkowanym na realizację zadań totalitarnego państwa. Nie spełnia znamion służby na rzecz totalitarnego państwa standardowa praca, która nie była ukierunkowana na realizację funkcji tego państwa ${ }^{27}$.

W procesie odkodowania treści pojęcia służby na rzecz państwa totalitarnego istotne znaczenie ma wykładnia systemowa i celowościowa. Pojęcie państwa totalitarnego z punktu widzenia aksjologii demokratycznego państwa prawnego ma jednoznacznie negatywne znaczenie ${ }^{28}$. W preambule Konstytucji RP jest mowa o gorzkich doświadczeniach z czasów, gdy podstawowe wolności i prawa człowieka były łamane. W uwagach wstępnych wskazano, że analizowane ustawy dezubekizacyjne mają na celu ograniczenie dodatków emerytalnych funkcjonariuszy komunistycznej policji politycznej, którzy naruszali podstawowe prawa człowieka oraz dopuszczali się zbrodni wobec osób broniących niepodległości i demokracji. Poszukując znaczenia służby na rzecz systemu totalitarnego, sądy czasem odwołują się także do preambuły ustawy lustracyjnej, w której wyjaśniono, że praca albo służba w organach bezpieczeństwa państwa komunistycznego polegała na zwalczaniu opozycji demokratycznej, związków zawodowych, stowarzyszeń, kościołów i związków wyznaniowych, łamaniu prawa do wolności słowa i zgromadzeń, gwałceniu prawa do życia, wolności, własności i bezpieczeństwa obywateli, a także była trwale związana z łamaniem praw człowieka i obywatela na rzecz komunistycznego ustroju totalitarnego ${ }^{29}$. Tylko taka indywidualna i kierunkowa działalność dla państwa totalitarnego może być uznana za służbę na jego rzecz. Nie wszyscy pracujący w służbach bezpieczeństwa zwalczali ruchy demokratyczne i niepodległościowe oraz łamali prawa człowieka, gdyż wielu z nich wykonywało typowe zadania, tak jak i później, po 1990 roku, na przykład wykrywali przemyt narkotyków, chronili granice itd. ${ }^{30}$

25 W. Jakimowicz, O definicjach i domniemaniach prawnych — studium przypadku, „Przegląd Prawa Publicznego" 2020, nr 7-8, s. 58.

${ }^{26}$ Ibidem, zob. też uchwała składu siedmiu sędziów Sądu Najwyższego z dnia 16 września 2020 roku, sygn. akt III UZP 1/20.

27 W. Jakimowicz, op. cit., s. 58.

28 Ibidem, s. 57-58.

29 Wyrok Sądu Apelacyjnego w Białymstoku z dnia 20 kwietnia 2021 roku, sygn. akt III AUa $824 / 20$.

${ }^{30}$ Uchwała składu siedmiu sędziów Sądu Najwyższego z dnia 16 września 2020 roku, sygn. akt III UZP 1/20. 
Z ustaleń wynika, że, po pierwsze, ustawodawca wprowadził wzruszalne domniemanie prawne, że każdy pracownik służb bezpieczeństwa PRL w latach 1944-1990 służył totalitarnemu państwu ${ }^{31}$. Po drugie, redukcja świadczeń emertytalnych byłych pracowników służb bezpieczeństwa PRL nie jest oparta na odpowiedzialności zbiorowej oraz wyłącznie formalnych kryteriach czasu oraz miejsca służby, ale musi uwzględniać indywidualną sytuację byłych funkcjonariuszy. Odmienna wykładnia oznaczałaby, że pomimo iż formalnie stronie służy odwołanie do sądu od obniżenia świadczenia emerytalnego, to w istocie rzeczy jest ono pozorne, bo pozbawione jakiejkolwiek skuteczności i efektywności. Innymi słowy, zaniechanie badania, czy konkretna osoba wykonywała zadania służące totalitarnemu państwu, znacząco ograniczyłoby kompetencje judykacyjną sądu ubezpieczeń społecznych, którego zadaniem jest sądowa kontrola ingerencji w prawa jednostki.

\section{Prawo do sądu w sprawach zaopatrzenia emerytalnego funkcjonariuszy zatrudnionych w organach bezpieczeństwa w latach 1944-1990 oraz reguły dowodzenia służby na rzecz państwa totalitarnego}

Jednym z praw podstawowych jest prawo do sądu (art. 45 ust. 1 Konstytucji RP), prawo do rzetelnego procesu (fair trial, art. 6 EKPC) i prawo do skutecznego środka sądowego (art. 47 Karty Praw Podstawowych). Prawo do sądu obejmuje między innymi prawo dostępu do sądu, czyli możliwości wszczęcia procesu; prawo do procedury zgodnej z wymogami sprawiedliwości, szybkości oraz jawności i w końcu prawo do rozstrzygnięcia sądowego. Sam formalny dostęp do drogi sądowej nie spełnia wymogu prawa do sądu. Konieczne jest dodatkowe zapewnienie aspektu materialnego, to jest możliwości dochodzenia skutecznej ochrony praw na drodze sądowej. Zatem w sytuacji ingerencji organu władzy publicznej w prawa jednostki ustawodawca musi zagwarantować formalny dostęp do sądu i materialnoprawną możliwość skutecznej ochrony sądowej ${ }^{32}$. Zasada państwa prawnego nie dopuszcza tworzenia postępowań wykluczających prawa jednostki do rzetelnego procesu (fair trial, art. 6 EKPC) bez zapewnienia tak zwanej równości broni stron i standardów procesu kontradyktoryjnego ${ }^{33}$. A zatem reguły

31 W. Jakimowicz, op. cit., s. 56.

32 Zob. E. Morawska, Klauzula państwa prawnego w Konstytucji RP na tle orzecznictwa Trybunału Konstytucyjnego, Torun 2003, s. 274-275.

33 Uchwała składu siedmiu sędziów Sądu Najwyższego z dnia 16 września 2020 roku, sygn. akt III UZP 1/20. O równości stron w sprawach cywilnych zob. wyrok ETPC z dnia 13 lutego 2003 roku, Bertuzzi v. Francja, skarga nr 36378/97, pkt 30-31. 
procesu należy wykładać przy poszanowaniu zasady równych praw procesowych stron w zakresie między innymi dowodzenia prawnie relewantnych okoliczności sprawy.

O nierówności procesowej pozycji stron w sprawach zaopatrzenia emerytalnego funkcjonariuszy zatrudnionych w organach bezpieczeństwa w latach 19441990 może świadczyć konstrukcja podstawy obniżenia tych świadczeń, o której mowa w art. $15 \mathrm{c}$ ust. 4 , art. $22 \mathrm{a}$ ust. $4 \mathrm{i}$ art. $24 \mathrm{a}$ ust. $3 \mathrm{w}$ zw. $\mathrm{z}$ art. $13 \mathrm{a}$ ustawy zaopatrzeniowej. Zgodnie z tymi przepisami podstawą do redukcji świadczeń z ubezpieczeń społecznych pracowników aparatu bezpieczeństwa PRL z lat 1944-1990 jest informacja IPN o przebiegu służby funkcjonariusza na rzecz totalitarnego państwa, o którą wnioskuje organ rentowy. Taka informacja zawiera dane osobowe funkcjonariusza, okresy służby na rzecz totalitarnego państwa, a także informację, czy dokumenty zgromadzone w archiwach IPN potwierdzają, że funkcjonariusz w tym okresie, bez wiedzy przełożonych, podjął współpracę i czynnie wspierał osoby lub organizacje działające na rzecz niepodległości państwa polskiego (art. 13a ust. 4 ustawy zaopatrzeniowej). Innymi słowy, informacja sporządzona przez IPN zawiera przede wszystkim dane, które wynikają z literalnego brzmienia art. 13b ustawy zabezpieczeniowej, to jest - wskazują czas i miejsce służby. Nie przedstawia zaś faktów, czy konkretny funkcjonariusz zwalczał ruchy niepodległościowe, naruszył prawa i wolności człowieka w celu utrwalenia władzy państwa totalitarnego. Jednocześnie ustawodawca przyjął, że do informacji IPN nie stosuje się przepisów kodeksu postępowania administracyjnego, w tym na przykład zasady czynnego udziału strony, prawa do bycia wysłuchanym czy też po prostu prawa do obrony. $Z$ tego może wynikać, że strona jest pozbawiona prawa do przedstawienia kontrfaktów, a informacja IPN ma charakter wiążący dla organu emerytalnego ${ }^{34}$. W tych okolicznościach powstaje pytanie, czy strona ma prawo do skutecznego środka prawnego, który umożliwi kontestowanie informacji IPN, której nie miała w toku postępowania przed organem. Na skutek odwołania od decyzji organu emerytalnego sprawa z postępowania administracyjnego zostaje przeniesiona do sądu ubezpieczeń społecznych, który nie tylko obowiązany jest merytorycznie rozpoznać sprawę co do istoty. Sąd, dążąc do prawdy materialnej, jest obowiązany przede wszystkim zagwarantować prawo stron do wyjaśniania okoliczności sprawy zgodnie z prawdą i bez zatajania czegokolwiek poprzez możliwość przedstawienia dowodów na poparcie ich twierdzeń (art. 3 Ustawy z dnia 17 listopada 1964 roku - kodeks postępowania cywilnego, dalej: $\mathrm{kpc})^{35}$. Dlatego też $\mathrm{w}$ orzecznictwie słusznie przyjmuje się, że sąd ubezpieczeń społecznych w sprawie o obniżenie świadczeń emerytalnych pracownika aparatu bezpieczeństwa PRL nie jest związany treścią informacji IPN. Instytut Pamięci

34 Wyrok Wojewódzkiego Sądu Administracyjnego w Warszawie z dnia 16 września 2019 roku, sygn. akt II SA/Wa 884/19. Odmiennie zob. wyrok Wojewódzkiego Sądu Administracyjnego w Warszawie z dnia 15 stycznia 2020 roku, sygn. akt II SA/Wa 1740/19.

35 Tekst jedn. Dz.U. z 2021 r. poz. 1805. 
Narodowej nie może przecież zastępować sądu w merytorycznym rozpoznaniu istoty sprawy ${ }^{36}$. Zgodnie $\mathrm{z}$ art. $11 \mathrm{kpc}$ sąd może być związany jedynie prawomocnym wyrokiem skazującym, który zapadł w postępowaniu karnym. Natomiast informacja IPN stanowi jedynie oświadczenie wiedzy co do czasu i miejsca służby, które może być podstawą decyzji o obniżeniu świadczeń z ubezpieczeń społecznych, ta zaś może być przedmiotem zaskarżenia do sądu, co otwiera drogę do merytorycznego rozpoznania sprawy, które musi być poprzedzone postępowaniem dowodowym w zakresie tego, czy świadczeniobiorca służył na rzecz totalitarnego państwa, ponieważ taka jest podstawowa funkcja sprawowania wymiaru sprawiedliwości przez sądy (art. 175 Konstytucji RP w zw. z art. 3 kpc) $)^{37}$.

Odnosząc się do mocy dowodowej informacji IPN, należy podkreślić, że jest to dokument urzędowy w rozumieniu art. $244 \S 1 \mathrm{kpc}$, przeciwko któremu strony mogą zgłaszać kontrdowody. W tym zakresie nie będzie miał zastosowania przepis z art. 247 kpc, który stanowi ograniczenie dla dowodów z zeznań świadków i przesłuchania stron przeciwko lub ponad osnowę dokumentu obejmującego czynność prawną, ponieważ informacja IPN o służbie na rzecz totalitarnego państwa nie obejmuje czynności prawnych. Ponadto w sprawach z zakresu ubezpieczeń społecznych nie stosuje się przepisów ograniczających dopuszczalność dowodu ze świadków i przesłuchania stron (art. $473 \mathrm{kpc})^{38}$. W tych sprawach każdy relewantny fakt $\mathrm{w}$ zakresie ustalenia prawa lub wysokości do świadczenia może być dowodzony wszelkimi dowodami przewidzianymi przez kodeks postępowania cywilnego. Jeżeli z informacji IPN lub dokumentów zgromadzonych przez pracodawcę wynika, że pracownik świadczył służbę na rzecz państwa totalitarnego, to ubezpieczony może przed sądem wykazywać, że w okresie zatrudnienia wykonywał typowe zadania służb mundurowych, przy czym nie zwalczał ruchów niepodległościowych, nie łamał prawa do wolności słowa i zgromadzeń, prawa do życia, wolności, własności i bezpieczeństwa obywateli, a także praw człowieka w celu utrzymania komunistycznego ustroju totalitarnego. Wszystkie dowody przedstawione przez strony, $\mathrm{w}$ tym również informacja $\mathrm{z}$ IPN, będą podlegały swobodnej ocenie na podstawie art. $233 \S 1 \mathrm{kpc}^{39}$.

Na skutek odwołania od decyzji organu emerytalnego o obniżeniu świadczeń z ubezpieczeń społecznych sąd będzie obowiązany do weryfikacji in concreto informacji IPN poprzez zbadanie, między innymi, w jakich jednostkach organizacyjnych administracji bezpieczeństwa ubezpieczony pracował, jaki był zakres zadań tej formacji, na czym rzeczywiście polegała praca świadczeniobiorcy i jaki

36 Postanowienie Sądu Najwyższego z dnia 9 grudnia 2011 roku, sygn. akt II UZP 10/11.

37 Uchwała składu siedmiu sędziów Sądu Najwyższego z dnia 16 września 2020 roku, sygn. akt III UZP 1/20, wyrok Trybunału Konstytucyjnego z 11 stycznia 2012 roku, sygn. akt SK 36/09; postanowienie NSA z dnia 12 stycznia 2018 roku, sygn. akt I OSK 2848/17.

38 Uchwała składu siedmiu sędziów Sądu Najwyższego z dnia 16 września 2020 roku, sygn. akt III UZP 1/20.

39 Postanowienie Sądu Najwyższego z dnia 22 kwietnia 2021 roku, sygn. akt I USK 96/21. 
był jego wpływ na funkcjonowanie totalitarnego państwa. Informacja IPN wyznacza jedynie ramy czasowe, które będą przedmiotem sądowej kontroli w zakresie, czy ubezpieczony faktyczne działał na korzyść totalitarnego państwa. Środkami dowodowymi mogą być zeznania osób inwigilowanych lub prześladowanych albo wobec których funkcjonariusz wykonywał typowe czynności z zakresu bezpieczeństwa, zbiory akt IPN osób, których prawa były łamane, dokumenty z politycznych spraw sądowych, szczególnie jeżeli funkcjonariusz na przykład brał udział w prowokacjach, inicjował lub składał fałszywe zeznania oraz inne dowody potwierdzające, że propagował i/lub wspierał działania totalitarnego państwa (na przykład zastraszał osoby o odmiennych poglądach ${ }^{40}$. Tym samym sąd, ustalając, czy służba ubezpieczonego może być kwalifikowana jako działanie na korzyść państwa totalitarnego, nie można ograniczyć się tylko do opinii służbowych i akt pracowniczych, ale musi uwzględniać inne środki dowodowe zaproponowane przez strony.

Powyższe potwierdza treść art. 15 c ust. 5-6, art. 22a ust. 5-6 i art. 24a ust. 4 i 6 ustawy zaopatrzeniowej. Przepisy te stanowią, że jeżeli osoba objęta domniemaniem służby na rzecz totalitarnego państwa udowodni, że przed 1990 rokiem bez wiedzy przełożonych podjęła współpracę i czynnie wspierała aktywistów lub organizacje działające na rzecz niepodległości państwa polskiego, to jej świadczenie emerytalne nie będzie podlegało obniżeniu. Skoro takie osoby wspierały ruchy niepodległościowe bez wiedzy swoich przełożonych, to bezcelowe jest dowodzenie tych okoliczności na podstawie opinii przełożonych. Ponadto jeżeli były funkcjonariusz, co do którego zachodzi domniemanie działania na rzecz totalitarnego państwa wykaże, że w okresie służby bez wiedzy przełożonych wspierał ruchy niepodległościowe, to zbyteczne jest prowadzenie dalszego postępowania dowodowego w przedmiocie pozostałych szczegółów jego pracy w aparacie bezpieczeństwa. Ustawodawca przyznał bowiem prymat działalności wspierającej ruchy niepodległościowe (art. 15 c ust. 5-6, art. 22a ust. 5-6 i art. 24a ust. 4 i 6 ustawy zaopatrzeniowej).

Niezależnie od tego funkcjonariusze objęci domniemaniem służby na rzecz państwa totalitarnego $\mathrm{w}$ określonych przypadkach mogą skorzystać ze środka prawnego w postępowaniu administracyjnym, który może prowadzić do wyłączenia opisanego mechanizmu redukcji świadczeń emerytalnych. Jednocześnie ustawodawca nie przewidział reguł kolizyjnych pomiędzy tym postępowaniem administracyjnym i sądowym. Zatem ubezpieczony, według własnego wyboru, może skorzystać ze środka administracyjnoprawnego lub sądowego, bądź też obydwu jednocześnie. Skorzystanie z tego pierwszego nie wyłącza możliwości odwołania do sądu powszechnego i na odwrót. $Z$ tych też powodów nie można zasadnie twierdzić, że droga administracyjnoprawna jest wyłączną płaszczyzną obalenia

40 Wyrok Sądu Apelacyjnego w Białymstoku z dnia 19 listopada 2020 roku, sygn. akt III AUa $115 / 20$ 
domniemania służby na rzecz państwa totalitarnego, która wyłącza wyżej opisane prawo do sądu. Środek administracyjnoprawny oraz prawo do odwołania do sądu ubezpieczeń społecznych nie stanowią konkurencyjnych i wykluczających się środków ochrony prawnej.

Drogę administracyjnoprawną reguluje przepis art. 8a ustawy zaopatrzeniowej, który stanowi, że minister właściwy do spraw wewnętrznych, w formie decyzji, w szczególnie uzasadnionych przypadkach, może wyłączyć obniżenie zaopatrzenia emerytalnego osób objętych domniemaniem prawnym służby na rzecz państwa totalitarnego w latach 1944-1990 ze względu na krótkotrwałą służbę przed dniem 31 lipca 1990 roku oraz rzetelne wykonywanie zadań i obowiązków po dniu 12 września 1989 roku, w szczególności z narażeniem zdrowia i życia. A zatem minister może skorzystać $\mathrm{z}$ tej dyskrecjonalnej kompetencji w kwalifikowanej sytuacji „szczególnie uzasadnionego przypadku” ze względu na fakt krótkotrwałej służby oraz rzetelnie wykonywanych zadań po 1989 roku, szczególnie z narażeniem zdrowia. Powierzchowna wykładnia tego przepisu mogłaby sugerować, że ustawodawca przewidział trzy przesłanki do zastosowania tego przepisu, jednakże przesłankę szczególnie uzasadnionych przypadków powiązał z kryterium krótkotrwałości służby i jej rzetelności ze zwrotem „ze względu”, który oznacza tyle co „,z uwagi na” lub „zważywszy na"41. A zatem ustawodawca nie wskazał trzech przesłanek decyzji o wyłączeniu obniżenia zaopatrzenia emerytalne osób objętych domniemaniem prawnym służby na rzecz państwa totalitarnego ${ }^{42}$. Samodzielną przesłanką takiej decyzji jest szczególnie uzasadniony przypadek. Jednocześnie ustawodawca dokonał egzemplifikacji, wyjaśniając, że szczególnie uzasadnionym przypadkiem może być służba krótkotrwała przed 1990 i rzetelna — po 1989 roku $^{43}$. Tego kwalifikowanego stanu nie można jednak sprowadzać tylko do sytuacji, w której funkcjonariusz krótkotrwale przed 1990 i rzetelnie po 1989 roku wykonywał swoją służbę, gdyż taki skutek ustawodawca mógłby osiągnąć, nie wprowadzając przesłanki szczególnie uzasadnionych przypadków i pozostawiając wyłącznie kryteria krótkotrwałości oraz rzetelności. Tym samym jeżeli nawet funkcjonariusz nie pracował krótkotrwale przed $1990 \mathrm{i}$ rzetelnie po 1989 roku, minister może wydać decyzję z art. 8a ustawy zaopatrzeniowej, o ile w sprawie wystąpi szczególnie uzasadniony przypadek. Skoro służba na rzecz organów bezpieczeństwa państwa komunistycznego polegała na zwalczaniu ruchów niepodległościowych i łamaniu praw człowieka w celu utrzymania

41 Zob. W. Jakimowicz, op. cit., s. 61.

42 Ibidem.

43 Nieco odmiennie W. Jakimowicz, który, z jednej strony, stwierdza, że kryteria krótkotrwałości i rzetelności służby nie stanowią przykładowego wskazania „,szczególnie uzasadnionego przypadku", a z drugiej — przyjmuje, że brak spełnienia jednego z tych kryteriów nie wyłącza automatycznie spełnienia przesłanki „szczególnie uzasadnionych przypadków” (ibidem, s. 62). 
komunistycznego ustroju, to szczególnie uzasadnionym przypadkiem jest praca funkcjonariusza, któremu nie można przypisać takiego postępowania ${ }^{44}$.

Rekapitulując tę część rozważań, należy podkreślić, że skoro minister w drodze decyzji administracyjnej może wyłączyć mechanizm obniżenia emerytury funkcjonariuszom objętym domniemaniem służby na rzecz państwa totalitarnego, to nie można ograniczać prawa do sądu do jej weryfikacji poprzez przyznanie prymatu opinii IPN nad prerogatywą sprawowania wymiaru sprawiedliwości ${ }^{45}$.

\section{Uwagi końcowe}

Celem ustaw dezubekizacyjnych jest ograniczenie przywilejów emerytalnych funkcjonariuszy policji politycznej, którzy służyli komunistycznemu ustrojowi poprzez naruszanie podstawowych praw człowieka i nie ponieśli z tego tytułu odpowiedzialności. Druga ustawa dezubekizacyjna miała zaostrzyć ten skutek. Na mocy art. 13b wprowadziła domniemanie prawne, że służbą na rzecz totalitarnego państwa jest służba od dnia 22 lipca 1944 do 31 lipca 1990 roku $\mathrm{w}$ wymienionych $\mathrm{w}$ tym przepisie cywilnych i wojskowych instytucjach lub formacjach. Bezrefleksyjna wykładnia tego przepisu może prowadzić do wniosku, że w tym zakresie decydują kryteria formalne: czas i miejsce służby. Jednakże takie rozumienie jest, po pierwsze, niezgodne $\mathrm{z}$ wspomnianym celem ustaw dezubekizacyjnych, bo ex lege uznałaby wszystkich funkcjonariuszy tych służb z tego okresu za winnych łamania praw człowieka, co prowadziłoby do odpowiedzialności zbiorowej. Po drugie, w istocie skutkowałaby zanikiem ochrony prawnej osób dotkniętych arbitralną oceną historii. To zaś prowadziłoby do przyjęcia mechanizmów sytemu, który jest przedmiotem rozliczeń. W ustroju totalitarnym nie ma bowiem miejsca na prawo do skutecznego środka prawnego i dostępu do bezstronnego sądu.

Niemniej jednak należy pamiętać, że wprawdzie demokratyczne państwo prawa jest uprawnione do rozliczeń z funkcjonariuszami reżimu, którzy łamali podstawowe prawa człowieka, a ochrona praw nabytych nie rozciąga się na uprawnienia przyznane niesprawiedliwie na przykład za naruszanie podstawowych wolności ${ }^{46}$. Jednakże taki mechanizm nie może pozbawić ubezpieczonych prawa do skutecznego środka prawnego. Świadczeniobiorca musi mieć prawo

44 Ibidem. Oczywiście w przypadku decyzji odmawiającej wyłączenia przepisów art. 15c, art. 22a i art. 24a ustawy zaopatrzeniowej strona będzie uprawniona do uruchomienia sądowoadministracyjnej kontroli legalności wykonywania kompetencji dyskrecjonalnych ministra w tym zakresie.

45 Uchwała składu siedmiu sędziów Sądu Najwyższego z dnia 16 września 2020 roku, sygn. akt III UZP $1 / 20$.

46 Wyrok ETPC z 14 maja 2013 roku, Cichopek i inni v. Polska, skarga nr 15189/10. 
obrony i kwestionowania przypisania mu służby na rzecz państwa totalitarnego. Dlatego domniemanie prawne $\mathrm{z}$ art. $13 \mathrm{~b}$ ustawy zaopatrzeniowej ma charakter wzruszalny - o wypełnieniu znamion służby na rzecz totalitarnego państwa nie decydują jedynie kryteria formalne: czasu i miejsca, lecz indywidualne czyny potwierdzające naruszenie podstawowych praw człowieka w celu utrzymania komunistycznego ustroju ${ }^{47}$.

\section{Bibliografia}

Arendt H., The Origins of Totalitarianism, [w:] On Violence, red. B.B. Lawrence, A. Karim, Durham 2007.

Brzeziński Z., Friedrich C.J., Totalitarian Dictatorship and Autocracy, New York-Washington-London 1956.

Dąbrowski M., Glosa do uchwały składu siedmiu sędziów Sądu Najwyższego z dnia 16 września 2020 r., sygn. akt III UZP 1/2020, „Przegląd Prawa Konstytucyjnego” 2021, nr 3.

Dąbrowski M., Odpowiedzialność funkcjonariuszy Policji i innych wspótczesnych formacji za petnienie slużby $w$ organach bezpieczeństwa PRL - aspekty konstytucyjne, „Przegląd Prawa Konstytucyjnego" 2018, $\mathrm{nr} 2$.

Izdebski H., Totalitaryzm i terminy pokrewne w naukach społecznych oraz w polskim języku prawnym i prawniczym, „Studia nad Autorytaryzmem i Totalitaryzmem” 38, 2016, nr 4.

Jakimowicz W., O definicjach i domniemaniach prawnych — studium przypadku, „Przegląd Prawa Publicznego" 2020, nr 7-8.

Kamenka E., Totalitaryzm, [w:] Przewodnik po współczesnej filozofii politycznej, red. R.E. Goddin, F. Pettit, Warszawa 1998.

Morawska E., Klauzula państwa prawnego w Konstytucji RP na tle orzecznictwa Trybunału Konstytucyjnego, Torun 2003.

Rakowska-Trela A., Obniżenie emerytur funkcjonariuszy stużb mundurowych nabytych poczawszy od 1990 r. a standardy konstytucyjne, „Gdańskie Studia Prawnicze” 40, 2018.

Scheffler T., Przestępstwo publicznego propagowania faszystowskiego lub innego totalitarnego ustroju państwa (art. 256 k.k.). Analiza doktrynologiczna wybranych wypowiedzi piśmiennictwa i judykatury. Część szczególna I, „Studia nad Autorytaryzmem i Totalitaryzmem” 40, 2018, $\mathrm{nr} 4$.

Shapiro L.B., Totalitarinism, London 1972.

47 Uchwała składu siedmiu sędziów Sądu Najwyższego z dnia 16 września 2020 roku, sygn. akt III UZP $1 / 20$. 